\title{
Analysis of a Rhizobium leguminosarum gene encoding a protein homologous to glutathione S-transferases
}

\author{
Najláa K. Tawfiq Alkafaf, Kay H. Yeoman,† Margaret Wexler, \\ Haitham Hussain and Andrew W. B. Johnston
}

Author for correspondence: Andrew W. B. Johnston. Tel: +44 1603 592264. Fax: +44 1603592250. e-mail: a.johnston@uea.ac.uk

School of Biological Sciences, University of East Anglia, Norwich NR4 7TJ, UK

\begin{abstract}
A novel Rhizobium leguminosarum gene, gstA, the sequence of which indicated that it was a member of the gene family of glutathione $S$ transferases (GSTs), was identified. The homology was greatest to the GST enzymes of higher plants. The Rhizobium gstA gene was normally expressed at a very low level. The product of gstA was over-expressed and purified from Escherichia coli. It was shown to bind to the affinity matrix glutathioneSepharose, but no enzymic GST activity with 1-chloro-2,4-dinitrobenzene as substrate was detected. gstA encoded a polypeptide of 203 amino acid residues with a calculated molecular mass of $21990 \mathrm{Da}$. Transcribed divergently from gstA is another gene, gst $R$, which was similar in sequence to the LysR family of bacterial transcriptional regulators. A mutation in gst $R$ had no effect on the transcription of itself or gstA under the growth conditions used here. Mutations in gstA and gstR caused no obvious phenotypic defect and the biological functions of these genes remain to be determined.
\end{abstract}

Keywords: glutathione, glutathione $S$-transferase, Rhizobium, transcriptional regulator

\section{INTRODUCTION}

Bacteria of the genera Rbizobium, Azorbizobium and Bradyrhizobium infect legume roots, inducing nodules in which the bacteria reduce atmospheric $\mathrm{N}_{2}$, making the resultant ammonia available to the host. In exchange, the bacteria obtain an exclusive source of fixed carbon from the plant. Over the past few years, there have been major advances in the understanding of the functions of many of the bacterial genes that are required for the early steps of the infection process and in the process of $\mathrm{N}_{2}$ fixation per se (Fischer, 1994; Spaink, 1995). There is, however, less information on the 'housekeeping' genes of the bacteria, some of which may also be required for symbiotic $\mathrm{N}_{2}$ fixation.

We had previously identified and sequenced several genes in a region of the chromosome of Rhizobium leguminosarum bv. viciae, the symbiont of peas and

†Present address: Institute of Food Research, Norwich Research Park, Colney Lane, Norwich NR4 7UA, UK.

Abbreviations: CDNB, 1-chloro-2,4-dinitrobenzene; GST, glutathione S-transferase.

The EMBL accession number for the sequence reported in this paper is X89816. vetches. This region contained the $c y c$ genes that are involved in the biosynthesis of cytochrome $c$ (Delgado et al., 1995) and the regulatory genes feuP and feuQ, which are required for the efficient uptake of iron (Yeoman et al., 1997).

During the course of studying this region, we identified another gene that specifies a protein with a striking similarity in sequence to proteins of the glutathione $S$ transferase (GST) family. These enzymes are multifunctional proteins that catalyse the conjugation of GSH via the thiol group to a large variety of hydrophobic electrophilic compounds (Jakoby \& Habig, 1980), resulting in their detoxification. They can also catalyse the reduction of peroxide molecules (Pickett \& Lu, 1989). In mammals, the cytosolic GST isozymes are of at least four distinct classes, alpha, mu, pi and theta, according to their substrate specificity, immunochemical reactivity and their primary amino acid sequences (Ogura et al., 1991; Mannervik et al., 1992; Meyer, D. J. et al., 1991). These enzymes have been widely studied in mammals and, to a lesser extent, in plants. In plants, GSTs can detoxify herbicides such as atrazine (Timmerman, 1989); they are also induced by pathogenic infection and are likely to be involved in defence responses (Dudler et al., 1991). 
There have been relatively few studies on GSTs in prokaryotes, although a recent survey showed that a wide range of Gram-negative soil bacteria have GST activity, albeit at a low level in most cases (Zablotowicz et al., 1995). Allocati et al. (1994) reported that in Proteus mirabilis, a GST-like protein was located in the bacterial periplasmic space. Morohoshi (1991) and Masai et al. (1991, 1993) cloned and sequenced a gene, ligF, from Pseudomonas paucimobilis which could direct the breakdown of aryl $\beta$-ether, resulting in the degradation of various dimeric lignin-based compounds. Sequence analysis revealed the deduced product of $\operatorname{lig} F$ to be similar to GSTs. Bacterial GST-like proteins have also been implicated in the bacterial breakdown of xenobiotics. Thus, Hofer et al. (1994) noted that the product of a gene involved in the catabolism of polychlorinated biphenyls by a strain of Pseudomonas had similarity to the GSTs of higher organisms. Furthermore, in two methylotrophs, Methylobacterium and Methylophilus, a gene, $\operatorname{dcm} A$, specifying a dichloromethane dehalogenase enzyme showed some similarity in sequence to members of the GST gene family (LaRoche \& Leisinger, 1990; Bader \& Leisinger, 1994). Interestingly, $d \mathrm{~cm} A$ of Methylobacterium is regulated by a divergently transcribed gene, $d c m R$ (LaRoche $\&$ Leisinger, 1991) for which the substrate dichloromethane is an inducer.

lizuka et al. (1989) described some of the properties of the GST of Escherichia coli. It is a homodimer with a substrate specificity towards 1-chloro-2,4dinitrobenzene (CDNB), a commonly used substrate for this family of enzymes. More recently, the gst gene of $E$. coli has been characterized at a molecular level; some low-level homology between the product of the E. coli gene and those of eukaryotes was detectable (Nishida $e t$ al., 1994) but the function of this gene is unknown.

Here, we describe the structure of a gst-like gene of $R$. leguminosarum, together with studies on its regulation and the properties of its purified gene product.

\section{METHODS}

Materials. GSH, equine liver GST, CDNB and Paraquat were from Sigma and atrazine was a gift from Ciba-Geigy. Restriction enzymes, T4 DNA ligase and Taq DNA polymerase were used according to the manufacturer's instructions (Boehringer Mannheim). Plasmid pET-21a was from Novagen. A pre-packed GSH-Sepharose 4B column was from Pharmacia. Specific 24-mer oligonucleotides were synthesized by Genosys or by Richard James (University of East Anglia) on a Bioresearch Cyclone Oligonucleotide Synthesizer.

Bacterial strains and plasmids. Bacterial strains and plasmids used in this study are listed in Table 1. General growth conditions and antibiotic concentrations for $E$. coli and $R$. leguminosarum were as described by Beringer (1974), unless otherwise stated.

DNA manipulations. DNA manipulations including cloning, Southern hybridization and transformations were done according to standard procedures (Sambrook et al., 1989). DNA sequencing was carried out with the aid of an ALF Pharmacia semi-automated sequencer according to the manufacturer's instructions. Double-stranded DNA was sequenced using the Sanger et al. (1977) dideoxy chain-termination method. Data were analysed using programs in the DNA Star package. DNA searches of the EMBL database were carried out using BLAST (part of the GCG program; Wisconsin Sequence Analysis Package, University of Wisconsin). PCR amplifications were performed on an Omnigene thermal cycler. The oligonucleotide sequences of the PCR primers used to amplify gst $A$ were as follows: 5' CTGCATATGAAACTCTACCATCAC $3^{\prime}$ (start codon bold) and 5' GTCAAGCTTCA TGCGGCAAGGCCG 3' (stop codon bold).

Transposon mutagenesis. Plasmids were transferred to $R$. leguminosarum by conjugation (Buchanan-Wollaston et al., 1980) using the mobilizing plasmid pRK2013 (Figurski \& Helinski, 1979). Tnlac mutagenesis of pBIO1000, which contains the gstA and gst $R$ genes cloned in the wide-hostrange plasmid pLAFR1, was performed as follows. pBIO1000 was transformed into E. coli strain A118, which contains a chromosomally located copy of Tnlac. The resultant strain was used as the donor in subsequent triparental matings with $R$. leguminosarum bv. viciae strain $8401 \mathrm{pRL} 1 \mathrm{JI}$ as the recipient. Transposon insertions into $8401 \mathrm{pRL} 1 \mathrm{JI}$ were selected on complete TY medium containing $400 \mu \mathrm{g}$ streptomycin $\mathrm{ml}^{-1}$ (8401pRL1JI), $5 \mu \mathrm{g}$ tetracycline $\mathrm{ml}^{-1}$ (pLAFRI) and $250 \mu \mathrm{g}$ kanamycin $\mathrm{ml}^{-1}$ (Tnlac). Transconjugants containing Tnlac in pBIO1000 arose at a frequency of approximately $10^{-6}$ per recipient. Plasmid DNA was isolated from transconjugants and using appropriate restriction enzymes the approximate sites and orientations of the Tnlac insertions were determined. For precise mapping of Tnlac insertions, the junctions between the ends of IS50L and the pBIO1000 DNA were sequenced. This was achieved using a fluorescently labelled 25-mer oligonucleotide primer designed to bind to part of the Tn5 inverted repeat. The primer had the sequence: $5^{\prime}$ TTCCCGTTTTCCAGGATCTGACTTC 3'.

Tnlac insertions in gst $A$ and gstR of pBIO1000 were incorporated into the $8401 \mathrm{pRL} 1 \mathrm{JI}$ genome by marker exchange (Ruvkun \& Ausubel, 1981) using the IncP1 plasmid pPH1JI to force the elimination of $\mathrm{pBIO} 1000$, as described by Downie et al. (1983).

Pea seedlings (Pisum sativum $\mathrm{cv}$. Wisconsin Perfection) were inoculated with mutant $R$. leguminosarum, then grown and assayed for nodule formation and nitrogen fixation (Beynon et al., 1980).

Construction of gstA/gstR promoter lacZ fusions. The gst $A /$ gst $R$ promoter region was cloned into the lac promoter probe plasmid pMP220 as follows. A 465 bp AvaII fragment from pBIO860 (spanning the entire intergenic region between gst $A$ and gstR, from nucleotides 1669 to 2134) was cloned into the Smal site of pUC18 (see Fig. 1). The orientation of the AvaII insert was determined using a PstI digest. The resultant clone was digested with either (1) EcoRI and $B a m \mathrm{HI}$ and the resulting EcoRI-BamHI fragment cloned into $B g l \mathrm{II}-E c o R I-$ digested pMP220 to yield pBIO1016 or (2) EcoRI and XbaI and the resulting EcoRI-XbaI fragment cloned into EcoRI-XbaI-digested pMP220 to form pBIO1017. In plasmids pBIO1016 and pBIO1017, the lacZ gene of pMP220 would be under the control of the gst $A$ and the $g s t R$ promoter, respectively.

Enzyme assays. $\beta$-Galactosidase assays in R hizobium were done as described by Rossen et al. (1985). GST activity was assayed essentially by the method of Habig et al. (1974), modified as follows. Cultures of $R$. leguminosarum were 
Table 1. Strains and plasmids used in this study

\begin{tabular}{|c|c|c|}
\hline Strain/plasmid & Relevant properties & Reference/source \\
\hline \multicolumn{3}{|c|}{ R. leguminosarum bv. viciae } \\
\hline $8401(\mathrm{pRL} 1 J \mathrm{I})$ & Derivative of 8401 carrying pRL1JI; Str ${ }^{\mathrm{r}}$ & Downie et al. (1983) \\
\hline $\mathrm{J} 102$ & Derivative of $8401 \mathrm{pRL} 1 \mathrm{JI}$ carrying gst $A:: \operatorname{Tn} 5 l a c$ & This work \\
\hline J106 & Derivative of $8401 \mathrm{pRL} 1 \mathrm{JI}$ carrying gstR: :Tn5lac & This work \\
\hline \multicolumn{3}{|l|}{ E. coli } \\
\hline JM101 & Host used for transformation & Messing (1979) \\
\hline DH $5 \alpha$ & Host used for transformation & Hanahan (1983) \\
\hline A118 & CC118 containing Tn 5 lacZ in its chromosome; $\mathrm{Km}^{\mathrm{r}}$ & Simon et al. (1989) \\
\hline BL21(DE3) & Host used for expression of gst $A$ & Novagen \\
\hline \multicolumn{3}{|l|}{ Plasmids } \\
\hline pKN16 & $\begin{array}{l}\text { Cosmid carrying } 30 \mathrm{~kb} \text { R. leguminosarum bv. viciae B155 } \\
\text { DNA, including gst } A \text { and gst }\end{array}$ & Nadler et al. (1990) \\
\hline pMP220 & Broad-host-range, promoter probe cloning vector, $\mathrm{Tc}^{\mathrm{r}}$ & Spaink et al. (1985) \\
\hline pPH1JI & Inc P-1 plasmid used for marker exchange; $\mathrm{Gm}^{\mathrm{r}}$ & Beringer et al. (1979) \\
\hline pRK2013 & Helper plasmid; contains RK2 tra genes; $\mathrm{Kan}^{\mathrm{r}}$ & Figurski \& Helinski (1979) \\
\hline pET-21a & Used for high-level gene expression; Amp ${ }^{r}$ & Novagen \\
\hline pUC18 & E. coli cloning vector $A^{A m p} p^{r}$ & Yanisch-Perron et al. (1985) \\
\hline pBIO1000 & Contains gst $A$ and gst $R$ cloned in pLAFR 1 & This work \\
\hline pBIO1016 & $\begin{array}{l}465 \text { bp Avall fragment containing predicted gst } A / R \\
\text { promoter (in gst } A \text { orientation) cloned in pMP } 220\end{array}$ & This work \\
\hline pBIO1017 & $\begin{array}{l}465 \text { bp Avall fragment containing predicted gst } A / R \\
\text { promoter (in gstR orientation) cloned in pMP220 }\end{array}$ & This work \\
\hline pBIO860 & $\begin{array}{l}\text { Derivative of pKN16 containing } g s t A \text { and } g s t R \text { cloned in } \\
\text { pUC18 }\end{array}$ & This work \\
\hline pBIO872 & 612 bp gst $A$ PCR fragment cloned in pET-21a & This work \\
\hline
\end{tabular}

grown overnight at $28^{\circ} \mathrm{C}$ to a cell density of approximately $10^{9} \mathrm{ml}^{-1}$. Cells were harvested by centrifugation and washed twice in buffer $\mathrm{K}(0 \cdot 1 \mathrm{M}$ potassium phosphate buffer, $\mathrm{pH} \mathrm{6.8}$; $1.0 \mathrm{mM}$ EDTA). The final pellet was resuspended in $10 \mathrm{ml}$ buffer $\mathrm{K}$ and disrupted using a French press. Disrupted cells were centrifuged $(48000 \mathrm{~g}, 40 \mathrm{~min})$ at $4{ }^{\circ} \mathrm{C}$. Cell-free extracts were maintained at $4^{\circ} \mathrm{C}$ until assayed, within $1-4 \mathrm{~h}$. The reaction mixture consisted of $1.0 \mathrm{mM}$ CDNB, $1.0 \mathrm{mM} \mathrm{GSH}$ and cell-free extract $(200 \mu \mathrm{l})$ in a total volume of $1.0 \mathrm{ml}$. The reaction was initiated by addition of GSH and enzyme activity was calculated using a molar extinction coefficient of $9.6 \mathrm{mM}^{-1} \mathrm{~cm}^{-1}$ at $340 \mathrm{~nm}$ and $25^{\circ} \mathrm{C}$. Control reactions (without enzyme) were included to determine non-enzymic CDNB-GSH conjugation, and the background reaction was monitored at $340 \mathrm{~nm}$ for $2 \mathrm{~min}$ before addition of GSH. A Philips PU8730 UV/VIS spectrophotometer was used. One unit of enzyme activity was defined as the amount of the enzyme catalysing the formation of $1 \mu \mathrm{mol}$ product $\mathrm{min}^{-1}$ (Habig et al., 1974). Specific activity was defined as the units of enzyme activity (mg protein) $)^{-1}$ as measured according to the method of Bradford (1976) with bovine serum albumin as a standard.

Over-expression of gstA in $\boldsymbol{E}$. coli. The gstA gene was amplified using the two 24-mer oligonucleotide primers listed above. One of the primers contained a NdeI site (CATATG) that overlapped the translational start site and the other had a $H$ indIII site (AAGCTT) that overlapped the gst A translational stop codon. The $612 \mathrm{bp}$ PCR product was cloned into Ndel-HindIII sites of the pET-21a expression vector as described by Novagen, and the resulting plasmid, pBIO872, was transformed into E. coli B strain BL21(DE3). To confirm that the fragment had been correctly cloned, the junctions of the vector and the insert were sequenced. An overnight culture $(0.2 \mathrm{ml})$ of strain BL21(pBIO872) containing $100 \mu \mathrm{g}$ ampicillin $\mathrm{ml}^{-1}$ was inoculated into $20 \mathrm{ml}$ of the same medium, and incubated with shaking at $37^{\circ} \mathrm{C}$ until the $\mathrm{OD}_{600}$ reached $0 \cdot 6-1 \cdot 0$. The lac gene inducer IPTG was added to a final concentration of $1 \mathrm{mM}$ and the incubation was continued for $3 \mathrm{~h}$ until the $\mathrm{OD}_{600}$ reached about $2 \cdot 0$. Cells were harvested and resuspended in SDS-PAGE sample buffer and analysed on SDS-polyacrylamide gels $(15 \%, \mathrm{w} / \mathrm{v}$, acrylamide). Proteins were detected by staining with Coomassie Blue R-250.

Purification of GstA protein. Cells from a 1 litre culture of $E$. coli BL21(pBIO872) which had been grown in LB in the presence of IPTG were harvested and washed in $40 \mathrm{ml}$ PBS (150 mM NaCl, $4 \mathrm{mM} \mathrm{NaH} \mathrm{PO}_{4}, 16 \mathrm{mM} \mathrm{Na}_{2} \mathrm{HPO}_{4}$, pH 7.4) containing $1 \%(\mathrm{v} / \mathrm{v})$ Triton X-100. The cells were centrifuged, then resuspended in $15 \mathrm{ml} \mathrm{PBS}$, and disrupted in a French press. Disrupted cells were centrifuged $(48000 \mathrm{~g}, 40 \mathrm{~min})$. The supernatant was applied to a GSH-Sepharose 4B column $(2 \mathrm{ml})$ equilibrated with PBS plus $1 \%(\mathrm{v} / \mathrm{v})$ Triton X-100, and the column was washed with $10 \mathrm{ml}$ PBS. The enzyme was eluted with $20 \mathrm{ml} 50 \mathrm{mM}$ Tris $/ \mathrm{HCl}(\mathrm{pH} 8.0)$ containing $5 \mathrm{mM}$ GSH. The GstA fractions were pooled, dialysed against water, concentrated by ultrafiltration with a Diaflo YM3 membrane (Amicon) and stored at $-80^{\circ} \mathrm{C}$. All operations in the purification procedure were performed at $4{ }^{\circ} \mathrm{C}$.

Electrospray mass spectrometry. Mass spectrometry was performed with a Fisons VG form (quadrupole) mass spectrometer fitted with a pneumatically assisted electrospray (ion spray) source and controlled by VG Mass Lynx software (VG 
Biotech). The carrier solvent was acetonitrile/water $(1: 1$, $\mathrm{v} / \mathrm{v})$; and the solution flow was at the rate of $10 \mu \mathrm{l} \mathrm{min}{ }^{-1}$ using a Hewlett Packard 1090 LC. Protein samples were dissolved in carrier solvent at a concentration of $20 \mathrm{pmol} \mu \mathrm{l}^{-1}$ containing formic acid $(0 \cdot 1 \%, \mathrm{v} / \mathrm{v})$, centrifuged at $5000 \mathrm{~g}$ for $2 \mathrm{~min}$ and then $20 \mu \mathrm{l}$ samples were injected directly into the carrier stream. Horse heart myoglobin was used as a standard.

\section{RESULTS AND DISCUSSION}

\section{Identification of $g s t A$ and a putative transcriptional regulator, gstR}

A wide-host-range cosmid, pKN16, containing approximately $30 \mathrm{~kb}$ cloned $R$. leguminosarum bv. viciae DNA, was isolated by Nadler et al. (1990). pKN16 contains 10 EcoRI fragments. One of these, $3.7 \mathrm{~kb}$ in size, lies approximately $5 \mathrm{~kb}$ upstream of the previously identified feuP gene (Yeoman et al., 1997). This fragment was cloned into pUC18 to form pBIO860. Various restriction fragments from pBIO860 were subcloned into pUC18 and their sequences were determined. The sequence of the entire $3.7 \mathrm{~kb}$ fragment was then completed, using appropriate primers designed to extend the contigs that had already been obtained.

The sequenced region was analysed for ORFs; it was clear that it contained two genes with homology to genes of known functions. One of these, which we term gst $A$, has a product that is similar to the GST enzyme family (see below). The other, termed gst $R$, is transcribed divergently from $g s t A$, the translational starts of the two genes being separated by $143 \mathrm{bp}$ (Fig. 1). The deduced GstR protein was similar to members of the LysR family of bacterial transcriptional regulators (see below).

In addition to these two genes, a DNA homology search (FASTA) showed that immediately downstream of the $g s t R$ stop codon there are 62 bp with $87 \%$ identity to a region of DNA in another strain (VF39) of $R$. leguminosarum bv. viciae. This is downstream of a gene, pss 4 , which specifies a glycosyltransferase that is required for one of the earliest steps in the synthesis of the acidic exopolysaccharide (Ivashina et al., 1994). Interestingly, another gene, $p s s A$, which corresponds in sequence and function to $p s s 4$, has also been identified in a strain of $R$.

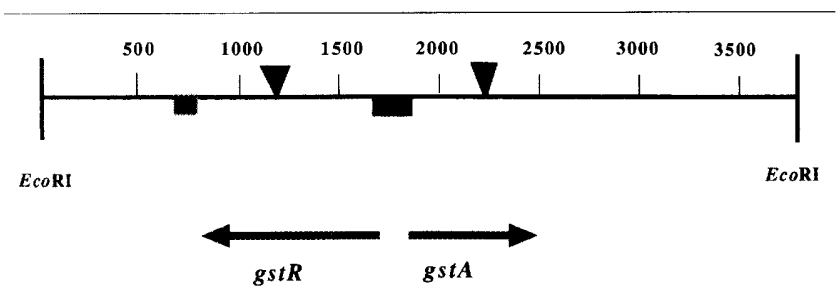

Fig. 1. Restriction map of the gstA/gstR region of $R$. leguminosarum cloned in $\mathrm{pBIO860}$. Numbers refer to the $\mathrm{bp}$ positions in the DNA sequence. The triangles represent the position of the Tn5lacZ insertions, the black box represents the promoter region and the dotted box shows the region of homology to the non-coding region of the pss 4 gene of $R$. leguminosarum bv. viciae VF39. leguminosarum bv. phaseoli (Borthakur et al., 1988). However, the DNA $3^{\prime}$ of $p s s A$ has no similarity to that downstream of $p s s 4$ and no similarity was found between the sequences in the vicinity of $p s s A$ and gstR.

\section{Comparison of $R$. leguminosarum GstA with other GSTs}

The deduced polypeptide product of gst $A$ has a calculated molecular mass of $21989 \mathrm{Da}$. A database search of its predicted amino acid sequence showed it to be homologous to a number of GST or GST-like sequences from plants, animals and other bacteria (Fig. 2). The similarity in sequence is most striking at the N-terminal end, in the regions of the GSTs that are most highly conserved amongst themselves. It has been proposed that the region between residues 51 and 82 (as shown in the GstA sequence in Fig. 2) is involved in binding the glutathione substrate so a priori would be expected to be well-conserved (Ketterer et al., 1988; TelakowskiHopkins et al., 1986; Tu \& Qian, 1986). However, the region of highly conserved sequence extends further towards the $\mathrm{N}$-terminus and there are other short patches of homology at other positions towards the C-terminus of the other GST proteins and GstA.

As indicated in the legend to Fig. 2, the overall incidence of similar or identical amino acids in GstA is greatest with the proteins of higher plants, rather than to those of animals or other bacteria. The evolutionary significance, if any, of these levels of similarity is not clear.

\section{Comparison of GstR and other proteins of the LysR family}

Comparison of the deduced protein sequence of the product of $g s t R$ with those in databases indicated that it was a member of the large family of bacterial transcriptional regulators of the so-called LysR family (see Schell, 1993). Generally, any two members of this family have approximately $20 \%$ identity with each other, and this was the overall value in pairwise comparisons of GstR with other individual proteins (not shown). The most highly conserved region is towards the $\mathrm{N}$-terminus and comprises a helix-turn-helix domain that is responsible for the binding of the proteins to regulatory DNA sequences (Schell, 1993). As shown in Fig. 3, the deduced sequence of GstR shares several of the consensus residues in this motif.

Members of the family also possess intermittent regions of conserved sequences throughout the length of the protein, these being involved in the recognition of the particular inducer molecule and for both the binding to DNA and the response to the inducer (Schell, 1993). The GstR protein shared several of these conserved sequences (not shown), but there were no extended regions of striking identity in the C-terminal region of GstR compared to the other regulators. This indicates that GstR is a novel member of the family and is likely to respond to a compound that does not act as an inducer with any other known member. 


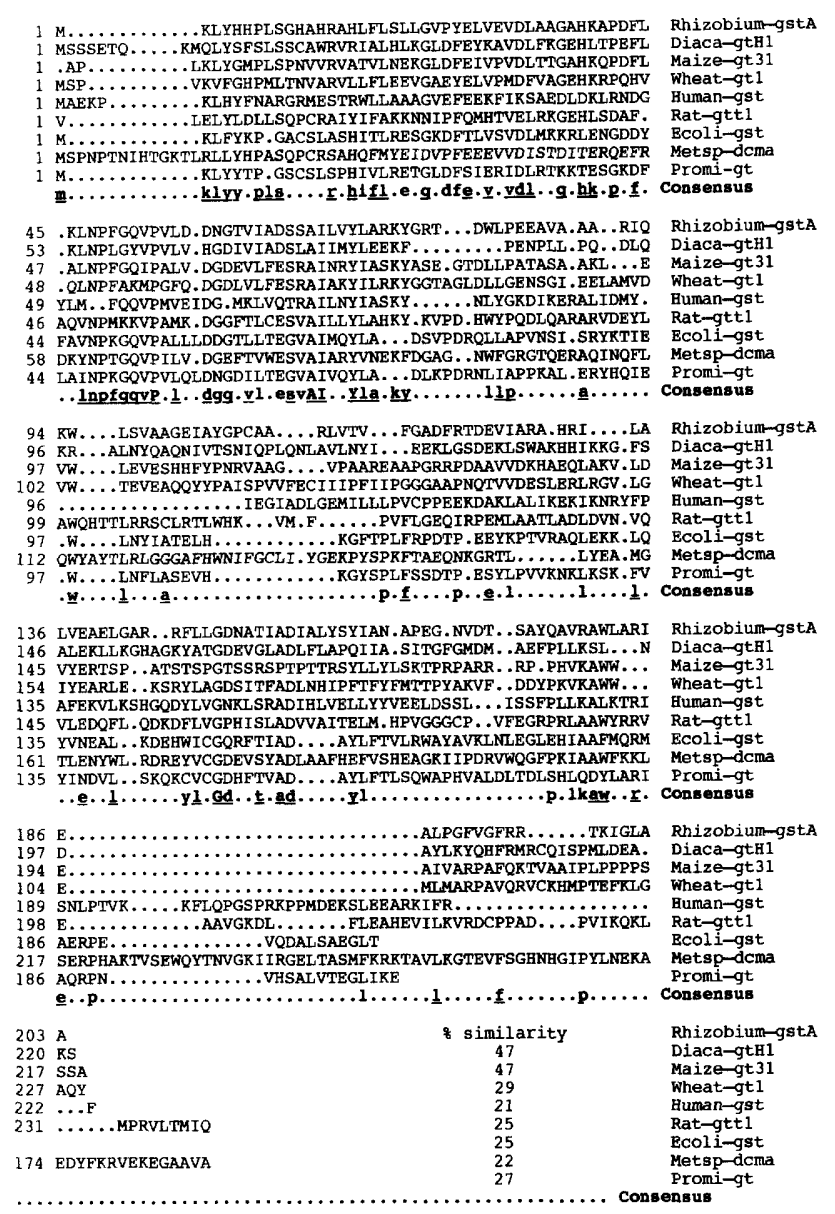

Fig. 2. Comparison of the deduced product of the $R$. leguminosarum gstA gene with other members of the GST family and related proteins. Amino acid sequences of GST from the plants Dianthus (Itzhaki \& Woodson, 1993), maize (Moore et al., 1986) and wheat (Dudler et al., 1991), the mammals human (Board \& Webb, 1987) and rat (Pemble \& Taylor, 1992), and the bacteria E. coli (Nishida et al., 1994), Proteus mirabilis (Mignogna et al., 1993) and Methylobacterium (LaRoche \& Leisinger, 1991) are shown. A consensus sequence is included in which amino acids that are entirely conserved are shown in upper case letters. For those residues where four or more amino acids are identical, the consensus is shown in lower case and where the Rhizobium sequence corresponds to the consensus, the letters are underlined. The percentage similarity indices (Lipman-Pearson protein alignment) of the Rhizobium GstA protein to other members of the family are shown.

\section{R. leguminosarum has low GST activity using CDNB as substrate}

Many GSTs from various organisms have been detected using $\mathrm{CDNB}$ as the substrate, although certain members of the enzyme family are unable to conjugate this molecule to GSH. It has been shown that one strain of $R$. leguminosarum, Ta1421, has low levels of GSHdependent GST activity with CDNB as the acceptor (Zablotowicz et al., 1995). To determine if $8401 \mathrm{pRL} 1 \mathrm{JI}$ also had GST activity with CDNB as substrate, cell-free extracts of this strain were assayed for the enzyme as described in Methods.

As a control, purified GST from equine liver was confirmed to generate a condensation product between GSH and CDNB with a major peak of absorbance at $340 \mathrm{~nm}$ and a minor one at $411 \mathrm{~nm}$. In contrast, when $R$. leguminosarum cell-free extract was used in the reaction, the $411 \mathrm{~nm}$ peak was the major one in comparison with that at $340 \mathrm{~nm}$. The band at $340 \mathrm{~nm}$ is due to the accumulation of the dinitrophenyl-glutathione (DNP-SG) conjugate, while the band at $411 \mathrm{~nm}$ is probably due to a further metabolism of the DNP-SG conjugate. Neither peak was observed if GSH or CDNB was omitted from the reaction mixture with the cell-free extract nor if the cell-free extracts were boiled prior to adding the substrates. Thus, using CDNB as a substrate, we conclude that $R$. leguminosarum bv. viciae strain 8401pRL1JI does contain GSH-dependent GST activity but, as with other bacteria (Zablotowicz et al., 1995), the activity was low $\left[0.052 \times 10^{-3}\right.$ units $\left.(\mathrm{mg} \text { protein })^{-1}\right]$.

Two maize GSTs have very little or no activity with CDNB as a substrate (Timmerman, 1989) but did have activity towards the herbicide atrazine. This indicates the importance of assaying with a variety of substrates when characterizing GST. Accordingly, R. leguminosarum strain $8401 \mathrm{pRL} 1 \mathrm{JI}$ was examined for its ability to condense GSH with the two herbicides atrazine and Paraquat. In each case, the concentration of substrate in the reaction mixture was $1 \mathrm{mM}$. There was no detectable GST activity when either molecule was used as substrate (not shown).

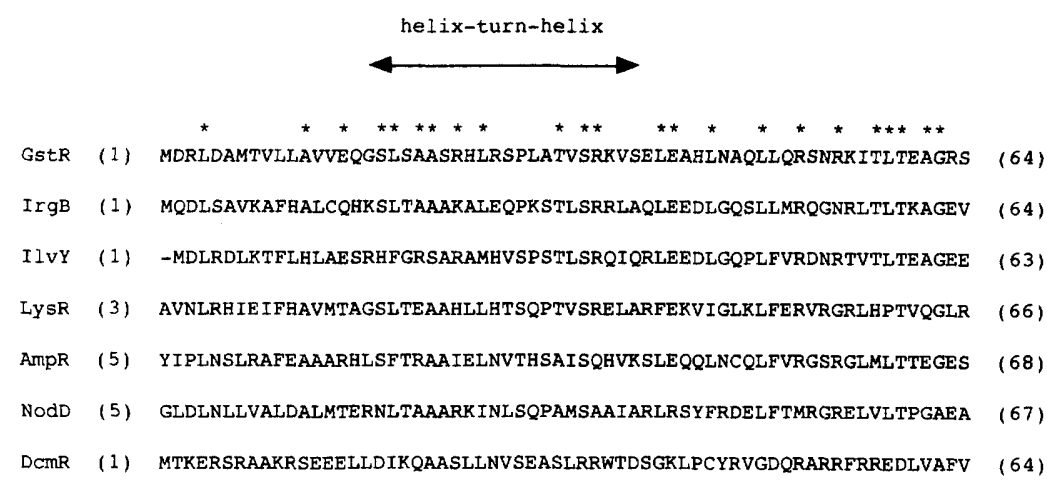

Fig. 3. Comparison of the $\mathrm{N}$-terminus of GstR and selected members of the LysR family of bacterial transcriptional activators (see Goldberg et al., 1991, IrgB; Wek \& Hatfield, 1986, IlvY; Henikoff et al., 1988, LysR; Honore et al., 1986, AmpR; Györgypal \& Kondorosi, 1991, NodD; LaRoche \& Leisinger, 1991, DcmR). Amino acids in GstR that are present in the corresponding position of two or more of the other regulators are indicated by asterisks. The numbers in parentheses refer to the distance of the amino acids from the N-termini of the proteins. The conserved helix-turn-helix domain of these proteins is also indicated. 
Table 2. Effect of gstR mutation on the expression of gstA-lacZ and gstR-lacZ

Plasmids pBIO1016 and pBIO1017, containing, respectively, the gst A-lacZ and gstR-lacZ fusions, were mobilized into wildtype strain $8401 \mathrm{pRL} 1 \mathrm{JI}$ and its gstR mutant derivative strain $\mathrm{J} 106 ; \beta$-galactosidase activities were measured as described by Rossen et al. (1985). As a control, the vector pMP220 was also introduced into each strain.

\begin{tabular}{|lc|}
\hline R. leguminosarum strain & $\begin{array}{c}\boldsymbol{\beta} \text {-Galactosidase activity } \\
\text { (Miller units) }\end{array}$ \\
\hline 8401pRL1JI(pMP220) & $60 \pm 10$ \\
8401pRL1JI(pBIO1016) & $72 \pm 12$ \\
8401pRL1JI(pBIO1017) & $305 \pm 18$ \\
J106(pMP220) & $69 \pm 10$ \\
J106(pBIO1016) & $75 \pm 8$ \\
J106(pBIO1017) & $280 \pm 12$ \\
\hline
\end{tabular}

\section{Induction of gstA}

It has been shown that the transcription of the $\operatorname{dcm} A$ gene (whose product has similarity to GST) was stimulated by growing the cells in the presence of the substrate dichloromethane (LaRoche \& Leisinger, 1991). This regulation depended upon the presence of the $d c m R$ gene that is transcribed divergently from the 'structural' gene $d c m A$. In an attempt to induce GST activity in R. leguminosarum, cells of strain $8401 \mathrm{pRL} 1 \mathrm{JI}$ were grown in media supplemented with CDNB $(10 \mu \mathrm{M})$, Paraquat $(50 \mu \mathrm{M})$ or atrazine $(500 \mu \mathrm{M})$ (these concentrations are not toxic to the cells). After $24 \mathrm{~h}$ growth in these supplemented media, cells were havested and assayed for GST activity, using CDNB as substrate. There was no increase in activity compared to the unsupplemented control, showing that if gst $A$ is inducible, these three compounds were ineffective as inducers.

\section{Effects of mutations in gstA and gstR}

To test if the gst genes that we had identified were responsible for the low level of GST activity in $R$. leguminosarum, we set out to isolate and characterize mutations in gst $A$ and gstR. Following mutagenesis of pBIO1000 with Tn5lac (see Methods), one insertion into $g s t A$ and one into gstR were isolated, their locations being shown in Fig. 1. In both mutants, the lacZ gene of Tn5lac was in the opposite orientation to that of the gst genes into which the transposon had inserted.

The gst $A:: \operatorname{Tn} 5 l a c$ and the gstR::Tn5lac mutations were each introduced by marker exchange into the genome of $R$. leguminosarum strain $8401 \mathrm{pRL} 1 \mathrm{JI}$; for each allele, two potential homogenates were checked by Southern blotting using the $3.7 \mathrm{~kb}$ EcoRI fragment from pBIO860 as a probe to genomic DNA isolated from the mutants. In all cases examined, the transposon had inserted into the corresponding position in the genomic DNA.
The gst A::Tn5lac and gstR::Tn5lac mutant strains were found to be prototrophic, have normal colony morphology and induced normal numbers of $\mathrm{N}_{2}$-fixing nodules on peas.

The two mutants were assayed for their GST activity, using CDNB as the substrate. In both cases, they had the same low-level activity as did the wild-type strain, whether or not the cells had been pregrown in the presence of CDNB. Thus it would seem that this low level of activity seen with CDNB as a substrate is not due to the $g s t A$ and $g s t R$ genes identified here. It therefore appears that $R$. leguminosarum possesses another gene encoding an enzyme, as yet uncharacterized, that is capable of a low level of GST activity with CDNB as the substrate.

\section{Effect of a gstR mutation on the transcription of gstR and gstA}

The $g s t R$ gene is transcribed divergently from $g s t A$, suggesting that gst $R$ might be involved in the regulation of gstA (see Schell, 1993). To test this, we examined the expression of both gst $A$ and $g s t R$ in the wild-type and in the gstR: :Tn5lac mutant strain that we had isolated. Note that in this gst $R$ mutant, the lac $Z$ gene was in the opposite orientation to gst $R$ itself and the levels of $\beta$ galactosidase in the gstR: $T$ Tn5lac mutant were essentially the same as in the control strain that lacked the transposon (Table 2).

To examine the expression of gst $A$ and gst $R$, we constructed transcriptional lac $Z$ fusions to the proposed promoter regions of both these genes. The gst $A$ and $g s t R$ genes each contain a single AvaII site (Fig. 1). The DNA between these two sites spans the intergenic region between $g s t A$ and $g s t R$ and so, presumably, contains the promoters for both these genes. This Avall fragment was cloned in both orientations into the wide-hostrange lacZ promoter probe vector $\mathrm{pMP} 220$ to form pBIO1016 (gstA promoter fusion) and pBIO1017 (gstR promoter fusion).

These two plasmids were each mobilized into the wildtype $R$. leguminosarum strain $8401 \mathrm{pRL} 1 \mathrm{JI}$ and into $8401 \mathrm{pRL} 1 \mathrm{JI}$ containing the Tn5lac insertion in gst $R$ (strain J106). These sets of transconjugants were grown in liquid minimal $\mathrm{Y}$ medium and assayed for $\beta$ galactosidase activity. As shown in Table 2 , in the wildtype background, expression of $g s t A-l a c Z$ was at a low level whereas that of $g s t R-l a c Z$ was relatively high. This is consistent with most other examples of the LysR family, in which the regulatory gene is expressed constitutively but the regulated genes are only transcribed at high levels when bacteria are exposed to an appropriate inducer (Schell, 1993). Essentially the same levels of transcription of both the gst $A-l a c Z$ and gst $R-l a c Z$ fusions were found in the gst $R$ mutant $\mathrm{J} 106$ as in the wild-type, $8401 \mathrm{pRL} 1 \mathrm{JI}$. Therefore, under the conditions used here, there is no evidence to show that $g s t R$ regulates itself or the adjacent gstA 'structural' gene. 


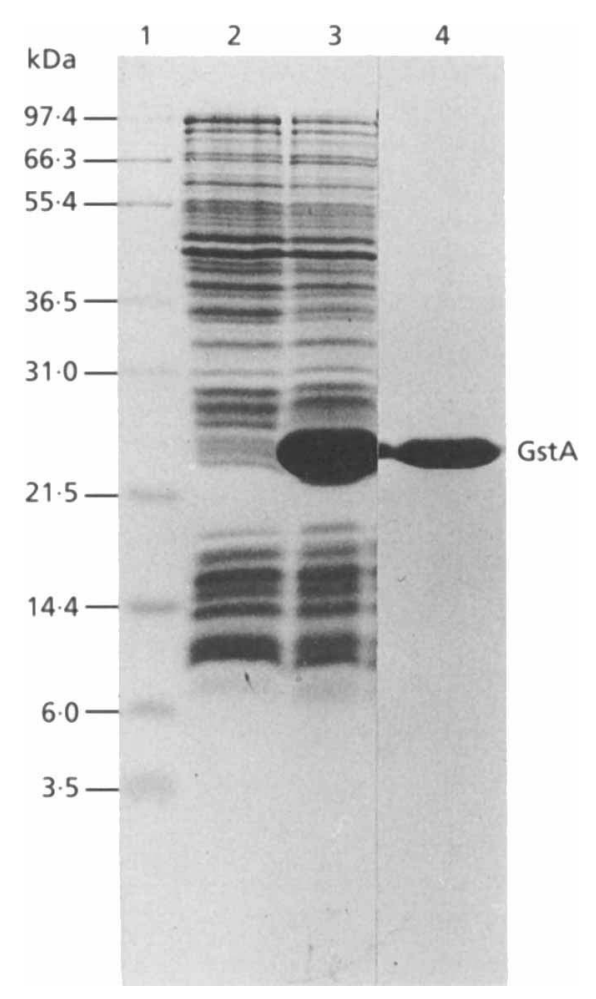

Fig. 4. Purification of $R$. leguminosarum GstA protein. Proteins were separated by PAGE. Lanes: 1, standard marker proteins; 2 , total proteins from extracts of $E$. coli pET-21a; 3 , over-expressed gst $A$ in $E$. coli; 4, purified protein after passage through the glutathione affinity column.

In most examples of the LysR family, the regulatory gene represses its own transcription independently of the presence of an inducer molecule (see Schell, 1993), although there are exceptions to this (Smit et al., 1992; Taira et al., 1991). Activation of transcription of any 'target' genes normally requires an inducer; it remains to be seen if $g s t R$ does in fact regulate $g s t A$ but that this only occurs in the presence of some as yet unidentified inducer molecule.

\section{Purification of the product of $R$. leguminosarum gst $A$}

To characterize some of the properties of the purified $R$. leguminosarum gst A gene product, gst $A$ was cloned into the expression vector pET-21a to form pBIO872 as described in Methods. Following induction of expression by the addition of IPTG to $E$. coli strain BL21(pBIO872), the most predominant single protein seen on a Coomassie-Blue-stained gel had an estimated size of approximately $22 \mathrm{kDa}$, consistent with that predicted from the DNA sequence of gstA (Fig. 4). This prominent protein band did not occur in the control strain containing only pET-21a or in extracts of cells containing pBIO872 to which no IPTG had been added.

To purify the GstA protein, cell-free extracts of $E$. coli containing the over-expressed $g s t A$ gene were loaded onto a GSH-Sepharose affinity column. After elution with GSH, samples were electrophoretically separated on a denaturing acrylamide gel. A single band was eluted with the expected molecular mass of approximately $22 \mathrm{kDa}$ for the GstA; this GSH-dependent elution of this protein clearly demonstrates that it does bind to GSH. To confirm that this protein corresponds to $R$. leguminosarum GstA, it was subjected to electrospray mass spectrometry to determine its exact molecular mass. This analysis identified two products, a major one (approximately $92 \%$ of the total signal) with a molecular mass of $22290 \mathrm{Da}$ and a minor one with a molecular mass of $21990 \mathrm{Da}$. The latter corresponds exactly in size to that predicted for the monomeric form of the GstA; the former is larger by $300 \mathrm{Da}$, which corresponds to the molecular mass of GSH. Thus each monomer of the R. leguminosarum GstA protein apparently binds covalently to a single molecule of the GSH that had been used to elute it from the column. This binding of GSH to the protein is most likely to be via a disulphide link. To confirm this, the protein sample that had been eluted from the GSH affinity column was treated with $1 \mathrm{mMDTT}$, dialysed excessively with water and its molecular mass was measured again. It was found that more than $95 \%$ of the protein had a molecular mass of $21990 \mathrm{Da}$, consistent with the DTT having reduced the disulphide bond which rendered the enzyme free of glutathione. Cell-free extracts from $E$. coli containing the over-expressed gst $A$ product and the purified protein were assayed for GST activity using CDNB plus GSH as substrates. Induction of gst $A$ expression with IPTG in the strain containing pBIO872 gave no detectable increase in activity above that from E. coli containing the plasmid vector alone. Likewise, assaying the purified GstA yielded no detectable GST activity, confirming that $\mathrm{CDNB}$ cannot act as a substrate for the product of $R$. leguminosarum gst $A$. Indeed, our finding is similar to that of a GSH-affinity binding protein obtained from Bacteroides fragilis, which binds to a GSH column but has no glutathione transferase activity (Piccolomini et al., 1991). Note further that CDNB has also been shown to be a poor substrate for certain GSTs from mammals (Jakoby \& Habig, 1980; Ketterer et al., 1988) and plants (Gronwald et al., 1987; Timmerman, 1989; Dean et al., 1990; Edwards \& Dixon, 1991; Meyer, D. J. et al., 1991), so this failure to catalyse the condensation of CDNB and GSH would not be unique.

The inability of the over-expressed gst $A$ to catalyse the condensation between GSH and CDNB is unlikely to be due to the need for some post-translational modification of the protein by E. coli. Most prokaryotic enzymes do not require any such modifications for their function. Further, it has been shown that eukaryotic gst genes specify functional GST enzymes, with the appropriate substrate specificity, when cloned in E. coli (Bernasconi et al., 1995).

Furthermore, immunoblotting analysis showed that none of the polyclonal antibodies raised against human GST $\alpha 1-1$ or rat GST YC $_{\mathrm{Z}}$ cross-reacted with the purified Rhizobium gstA gene product, but they $\operatorname{did}$ 
recognize equine GST (N. K. Tawfiq Alkafaf, unpublished results). This indicates that the antigenic domain of bacterial GSTs is different from those of mammals, a property that has been noted before in bacterial GSTs (Di Ilio et al., 1991).

\section{Concluding remarks}

The role of most bacterial GSTs remains something of an enigma. In some bacteria that have particular catabolic pathways that allow them to detoxify certain xenobiotics such as dichloromethane, the proteins responsible have some sequence similarity to eukaryotic GSTs (Hofer et al., 1994; Masai et al., 1991, 1993; LaRoche \& Leisinger, 1991). However, the ability to condense GSH to substrates such as CDNB appears to be quite widespread in prokaryotes (Zablotowicz et al., 1995) and there have been reports of GSH-binding proteins from other bacteria (Piccolomini et al., 1991). However, other than these particular cases in which GST-like proteins are involved in the catabolism of unusual compounds, there is no clear biological role for this enzyme in bacteria such as E. coli, Haemophilus influenzae (where a gstA-like gene has been identified from sequencing; Fleischmann et al., 1995) or, as described here, R. leguminosarum.

Future work will involve attempts to identify active substrates for the gstA gene product of $R$. leguminosarum and to examine if there are any inducer molecules that might activate transcription of gst A through the action of $g s t R$. Since an insertion mutation in gst $A$ did not abolish the low levels of GST activity, there is also scope to characterize the protein and the gene responsible for this activity.

\section{ACKNOWLEDGEMENTS}

This work was funded for the most part by the BBSRC of the UK. We are grateful to Rick Evans-Gowing for his help with the electrospray mass spectrometry, to Richard James for the synthesis of oligonucleotides and to Ann Reilly and James Stevens for their assistance. Also, we are grateful to Dr John Hayes for his kind gift of the anti-GST antisera.

\section{REFERENCES}

Allocati, N., Cellini, L., Aceto, A., lezzi, T., Angelucci, S., Robuffo, I. \& Ilio, C. D. (1994). Immunogold localization of glutathione transferase B1-1 in Proteus mirabilis. FEBS Lett 354, 191-194.

Bader, R. \& Leisinger, T. (1994). Isolation and characterization of the Methylophilus sp. strain DM11 gene encoding dichloromethane dehalogenase/glutathione $S$-transferase. J Bacteriol 176, 3466-3473.

Beringer, J. E. (1974). R factor transfer in Rhizobium leguminosarum. J Gen Microbiol 84, 179-185.

Beringer, J. E., Brewin, N. J., Johnston, A. W. B., Schulman, H. M. \& Hopwood, D. A. (1979). The Rhizobium-legume symbiosis. Proc R Soc Lond Ser B 204, 219-233.

Bernasconi, P., Woodworth, A. R., Ronsen, B. A., Subramanian, M. V. \& Siehl, D. L. (1995). A naturally occurring point mutation confers broad range tolerance to herbicides that target acetolactate synthase. J Biol Chem 270, 17381-17385.
Beynon, J. L., Beringer, J. E. \& Johnston, A. W. B. (1980). Plasmids and host-range in Rhizobium leguminosarum and Rhizobium phaseoli. J Gen Microbiol 120, 421-429.

Board, P. G. \& Webb, G. C. (1987). Isolation of a cDNA clone and localization of human glutathione $S$-transferase 2 genes to chromosome band 6p12. Proc Natl Acad Sci USA 84, 2377-2381.

Borthakur, D., Barker, R. F., Latchford, J. W., Rossen, L. \& Johnston, A. W. B. (1988). Analysis of pss genes of Rhizobium leguminosarum required for exopolysaccharide production and nodulation of peas: their primary structure and their interaction with $p s i$ and other nodulation genes. Mol Gen Genet 213, 155-162.

Bradford, M. M. (1976). A rapid and sensitive method for the quantitation of microgram quantities of protein utilizing the principle of protein-dye binding. Anal Biochem 72, 248-254.

Buchanan-Wollaston, A. V., Beringer, J. E., Brewin, N. J., Hirsch, P. R. \& Johnston, A. W. B. (1980). Isolation of symbiotically defective mutants in Rhizobium leguminosarum by insertion of the transposon Tn5 into a transmissible plasmid. Mol Gen Genet 178, 185-190.

Dean, V. J., Gronwald, J. W. \& Eberle, C. V. (1990). Induction of glutathione $S$-transferase isozymes in sorghum by herbicide antidotes. Plant Physiol 92, 467-473.

Delgado, M. J., Yeoman, K. H., Wu, G., Vargas, C., Davies, A. E., Poole, R. K., Johnston, A. W. B. \& Downie, J. A. (1995). Characterization of the $c y c H J K L$ genes involved in cytochrome $c$ biogenesis and symbiotic nitrogen fixation in Rhizobiumleguminosarum. J Bacteriol 177, 4927-4934.

Di Ilio, C., Aceto, A., Piccolomini, R., Allocati, N., Faraone, A., Bucciarelli, T., Barra, D. \& Federici, G. (1991). Purification and characterisation of a novel glutathione transferase from Serratia marcescens. Biochim Biophys Acta 1077, 141-146.

Downie, J. A., Hombrecher, G., Ma, Q. S., Knight, C. D., Wells, B. \& Johnston, A.W. B. (1983). Cloned nodulation genes of Rhizobium leguminosarum determine host-range specificity. Mol Gen Genet 190, 359-365.

Dudler, R., Hertig, C., Rebmann, G., Bull, J. \& Mauch, F. (1991). A pathogen-induced wheat gene encodes a protein homologous to glutathione-S-transferases. Mol Plant-Microbe Interact 4, 14-18.

Edwards, R. \& Dixon, R.A. (1991). Glutathione S-cinnamoyl transferases in plants. Pbytochemistry 30, 79-84.

Figurski, D. H. \& Helinski, D. R. (1979). Replication of an origincontaining derivative of plasmid RK2 dependent on a plasmid function provided in trans. Proc Natl Acad Sci USA 76, 1648-1652.

Fischer, H. M. (1994). Genetic regulation of nitrogen fixation in rhizobia. Microbiol Rev 58, 352-386.

Fleischmann, R. D., Adams, M. D., White, O. \& 37 other authors (1995). Whole genome random sequencing and assembly of Haemophilus influenzae RD. Science 269, 496-512.

Goldberg, M. B., Boyko, S. A. \& Calderwood, S. B. (1991). Positive transcriptional regulation of an iron-regulated virulence gene in Vibrio cholerae. Proc Natl Acad Sci USA 88, 1125-1129.

Gronwald, J. W., Fuerst, E. P., Eberlein, C. V. \& Egli, M. A. (1987). Effect of herbicide antidotes on glutathione content and glutathione S-transferase activity of sorghum shoots. Pestic Biochem Physiol 29, 66-76.

Györgypal, Z. \& Kondorosi, A. (1991). Homology of the ligand binding region of Rhizobium symbiotic regulatory protein NodD and vertebrate nuclear receptors. Mol Gen Genet 226, 337-340. 
Habig, W. H., Pabst, M. J. \& Jakoby, W. B. (1974). Glutathione Stransferases: the first enzymatic step in mercaptric acid formation. J Biol Chem 249, 7130-7139.

Hanahan, D. (1983). Studies on transformation of Escherichia coli with plasmids. J Mol Biol 166, 557-580.

Henikoff, S., Haughn, G. W., Calvo, J. M. \& Wallace, J. C. (1988). A large family of bacterial activator proteins. Proc Natl Acad Sci USA 85, 6602-6606.

Hofer, B., Backhaus, S. \& Timmis, K. N. (1994). The biphenyl/ polychlorinated biphenyl-degradation locus $(b p h)$ of Pseudomonas SP:LB400 encodes four additional metabolic enzymes. Gene 144, 9-16.

Honore, N., Nicolas, M. H. \& Cole, S.T. (1986). Inducible cephalosporinase production in clinical isolates of Enterobacter cloacae is controlled by a regulatory gene that has been detected from Escherichia coli. EMBO J 5, 3709-3714.

lizuka, M., Inoue, Y., Murata, K. \& Kimura, A. (1989). Purification and some properties of glutathione $S$-transferase from Escherichia coli B. J Bacteriol 171, 6039-6042.

Itzhaki, H. \& Woodson, W. R. (1993). Characterization of an ethylene-responsive glutathione $\mathrm{S}$-transferase gene cluster in carnation. Plant Mol Biol 22, 43-58.

Ivashina, T. V., Khmelnitsky, M. I., Shlyapnikov, M. G., Knanpin, A. A. \& Ksenzenko, V. N. (1994). The pss4 gene from Rhizobium leguminosarum bv. viciae VF 39: cloning, sequencing and the possible role in polysaccharide production and nodule formation. Gene 150, 111-116.

Jakoby, W. B. \& Habig, W. H. (1980). Glutathione S-transferases. In Enzymatic Basis of Detoxification, pp. 63-94. Edited by W. B. Jakoby. New York: Academic Press.

Ketterer, B., Meyer, D. \& Clark, A. G. (1988). Glutathione conjugation mechanisms and biological significance. In Soluble Glutathione Transferase Isozymes, pp. 73-135. Edited by H. Sies $\&$ B. Ketterer. London: Academic Press.

LaRoche, S. D. \& Leisinger, T. (1990). Sequence analysis and expression of the bacterial dichloromethane dehalogenase structural gene, a member of the glutathione-S-transferase supergene family. J Bacteriol 172, 164-171.

LaRoche, S. D. \& Leisinger, T. (1991). Identification of $d c m R$, the regulatory gene governing expression of dichloromethane dehalogenase in Methylobacterium sp. strain DM4. J Bacteriol 173, 6714-6721.

Mannervik, B., Awasthi, Y. C., Board, P. G., Hayes, J. D., Di llio, C., Ketterer, B., Listowsky, I., Moryenstern, R., Muramatsu, M., Pearson, W. R., Pickett, C. B., Sato, K., Widersten, M. \& Wolf, C. R. (1992). Nomenclature of human glutathione transferases. Biochem J 282, 305-308.

Masai, E., Katayama, Y., Kawai, S., Nishikawa, S., Yamasaki, M. \& Morohoshi, N. (1991). Cloning and sequencing of the gene for a Pseudomonas paucimobilis enzyme that cleaves beta-aryl ether. $J$ Bacteriol 173, 7950-7955.

Masai, E., Katayama, Y., Kubota, S., Kawai, S., Yamasaki, M. \& Morohoshi, N. (1993). A bacterial enzyme degrading the model lignin compound $\beta$-etherase is a member of the glutathione-Stransferase superfamily. FEBS Lett 323, 135-140.

Messing. J. (1979). A multipurpose cloning system based on single-stranded DNA bacteriophage M13. Recomb DNA Tech Bull 2, 43-48.

Meyer, D. J., Coles, B., Pemble, S. E., Gilmore, K. S., Fraser, G. M. \& Ketterer, B. (1991). Theta, a new class of glutathione transferases purified from rat and man. Biochem J 274, 409-414.
Meyer, R. C., Goldsbrough, P. B. \& Woodson, W. R. (1991). An ethylene-responsive flower senescence-related gene from carnation encodes protein homologous to glutathione $S$-transferases. Plant Mol Biol 17, 277-281.

Mignogna, G., Allocati, N., Aceto, A., Piccolomini, R., Di llio, C., Barra, D. \& Martini, F. (1993). The amino acid sequence of glutathione transferase from Proteus mirabilis, prototype of a new class of enzymes. Biochemistry 211, 421-425.

Moore, R. E., Davies, M. S., O'Connel, K. M., Harding, E. I., Wiegand, R. C. \& Tiemeier, D. C. (1986). Cloning and expression of a cDNA encoding a maize glutathione $S$-transferase in $E$. coli. Nucleic Acids Res 18, 7227-7235.

Morohoshi, N. (1991). Cloning and sequencing of the gene for a Pseudomonas paucimobilis enzyme that cleaves $\beta$-aryl ethers. J Bacteriol 73, 7950-7955.

Nadler, K. D., Johnston, A. W. B., Chen, J. W. \& John, T. R. (1990). A Rhizobium leguminosarum mutant defective in symbiotic iron acquisition. J Bacteriol 172, 670-677.

Nishida, M., Kong, K. H., Inoue, H. \& Takahashi, K. (1994). Molecular cloning and site-directed mutagenesis of glutathioneS-transferase from Escherichia coli; the conserved tyrosyl residue near the $\mathrm{N}$-terminus is not essential for catalysis. J Biol Chem 269, 32536-32541.

Ogura, K., Nishiyama, T. \& Watabe, T. (1991). Molecular cloning and amino acid sequencing of rat liver class theta glutathione $S$ transferases Yrs-Yrs inactivating reactive sulfate esters of carcinogenic arylmethanols. Biochem Biophys Res Commun 181, 1294-1300.

Pemble, S. E. \& Taylor, J. B. (1992). An evolutionary perspective on glutathione transferase inferred from class-theta glutathione transferase cDNA sequences. Biochem J 287, 957-963.

Piccolomini, R., Aceto, A., Allocati, N., Faraone, A. \& Di llio, C. (1991). Purification of a GSH-affinity binding protein from Bacteroides fragilis devoid of glutathione transferase activity. Microbiol Lett 82, 101-106.

Pickett, C. B. \& Lu, A. Y. H. (1989). Glutathione S-transferases: gene structure, regulation and biological function. Annu Rev Biochem 58, 743-764.

Rossen, L., Shearman, C. A., Johnston, A. W. B. \& Downie, J. A. (1985). The nodD gene of Rhizobium leguminosarum is autoregulatory and in the presence of plant root exudate induces the nod $A B C$ genes. EMBO J 4, 3369-3374.

Ruvkun, G. B. \& Ausubel, F. M. (1981). A general method for sitedirected mutagenesis in procaryotes. Nature 289, 85-88.

Sambrook, J., Fritsch, E. F. \& Maniatis, T. (1989). Molecular Cloning: a Laboratory Manual, 2nd edn. Cold Spring Harbor, NY: Cold Spring Harbor Laboratory.

Sanger, F., Nicklen, S. \& Coulson, A. R. (1977). DNA sequencing with chain-terminating inhibitors. Proc Natl Acad Sci USA 74, 5463-5467.

Schell, M. A. (1993). Molecular biology of the LysR family of transcriptional regulators. Annu Rev Microbiol 47, 597-626.

Simon, R., Quamlt, J. \& Klipp, W. (1989). New derivatives of transposon Tn 5 suitable for mobilisation of replicons, generation of operon fusions and induction of genes in Gram negative bacteria. Gene 80, 161-169.

Smit, G. V., Puvanesrajah, V., Carlson, R. W., Barbour, W. M. \& Stacey, G. (1992). Bradyrbizobium nodD1 can be specifically induced by soybean flavonoids that do not induce the nod YABCSUIJ operon. J Biol Chem 267, 310-318. 
Spaink, H. P. (1995). The molecular basis of infection by rhizobia; the ins and outs of sympathogenesis. Annu Rev Phytopathol 33, $345-368$.

Spaink, H. P., Okker, R. J. H., Wijffelman, C. A., Pees, E. \& Lugtenberg, B. J. J. (1985). Promoters in the nodulation region of the Rhizobium leguminosarum symbiotic plasmid pRL1JI. Plant Mol Biol 9, 27-39.

Taira, S., Riikonen, P., Saarilahti, H., Sukupolvi, S. \& Rhen, M. (1991). The $m k a C$ virulence gene of Salmonella serovar typhimurium $96 \mathrm{~kb}$ virulence plasmid encodes a transcriptional activator. Mol Gen Genet 228, 381-384.

Telakowski-Hopkins, C. A., Rothkopf, G. S. \& Pickett, C. B. (1986). Structural analysis of a rat liver glutathione $S$-transferase $\mathrm{Y} \propto$ gene. Proc Natl Acad Sci USA 83, 9393-9397.

Timmerman, K. P. (1989). Molecular characterisation of corn glutathione $S$-transferase isozymes involved in herbicide detoxification. Physiol Plant 77, 465-471.

Tu, C.-P. D. \& Qian, B. (1986). Human liver glutathione $S$ transferases: complete primary sequence of an $\mathrm{H}_{\mathrm{a}}$ subunit $\mathrm{cDNA}$. Biochem Biophys Res Commun 141, 229-237.
Wek, R. C. \& Hatfield, G. W. (1986). Nucleotide sequence and in vivo expression of the ilv $Y$ and ilv $C$ genes in Escherichia coli K12. $J$ Biol Chem 261, 2441-2450.

Yanisch-Perron, C., Vieira, J. \& Messing, J. (1985). Improved M13 phage cloning vectors and host strains : nucleotide sequence of the M13mp18 and pUC19 vectors. Gene 33, 103-119.

Yeoman, K. H., Delgado, M.-J., Wexler, M., Downie, J. A. \& Johnston, A.W. B. (1997). High affinity iron acquisition in Rhizobium Leguminosarum requires the $c y c H J K L$ operon and the feuPQ gene products, which belong to the family of twocomponent transcriptional regulators. Microbiology 143, 127-134.

Zablotowicz, R. M., Hoagland, R. E., Locke, M. A. \& Hickey, J. M. (1995). Glutathione-S-transferase activity and metabolism of glutathione conjugates by rhizosphere bacteria. Appl Environ Microbiol 61, 1054-1060.

Received 24 May 1996; revised 10 October 1996; accepted 22 October 1996. 